\title{
Foreign Experience and Current Legal Prospects Related to the Termination of a Labor Contract on the Initiative of an Employee and Agreement of Parties
}

\author{
Abdullaeva Dilfuza, Sobirov Bobur, Sarimsakova Gulnar, Burkhankhadjaeva Khurshida
}

\begin{abstract}
This article studies foreign experience (France, Germany, Great Britain, USA, Japan, CIS) and current legal prospects related to the termination of the labor contract on the initiative of an employee and with the agreement of parties. The research analyzes the international standards and mechanisms in termination of the labor contract, legal regulations of termination of the labor contract on the initiative of an employee and with the agreement of parties in foreign countries. This legal institution is of great importance in the CIS, and it differs from the European model of contractual regulation of labor relations. The issues in the Republic of Uzbekistan dealing with a draft, amendment, termination of an employment contract have been investigated, and a number of proposals and recommendations to improve the legislation have been developed.
\end{abstract}

Keywords: labor contract, on the initiative of an employee, termination of labor contract, amending employment contracts, foreign experience, employee rights, employer obligations, employer rights, electronic labor contracts, automated system.

\section{INTRODUCTION}

The aim of the research: to draw up scientifictheoretical and practical proposals to improve the legislation of amending and terminating labor contracts, to draft an employment contract based on comprehensive study of foreign experience and current legal prospects related to the termination of the labor contract on the initiative of the employee and with the agreement of parties.

Actuality and discussion:

\section{INTERNATIONAL STANDARDS AND MECHANISMS IN TERMINATION OF EMPLOYMENT CONTRACTS}

International labor standards are interstate agreements regulating issues related to the use of hired labor, improving its conditions, protection of labor, protection of personal and collective interests of employees, and the main result of international legal regulation of labor. Documents adopted by the UN, ILO and regional associations, and their norms,

Revised Manuscript Received on 14, October 2019.

Abdullaeva Dilfuza, Teacher of the Department of Labor, Law, Tashkent State University of Law, Uzbekistan(Email

Sobirov Bobur, Teacher of he Department of International Public Law, Tashkent State University of Law, Uzbekistan

Sarimsakova Gulnar, Head of the Department of Labor Law, Tashkent State University of Law, Uzbekistan(Email: g.sarimsakova@tsul.uz)

Burkhankhadjaeva Khurshida, Associate Professor of the Department of Labor Law, Tashkent State University of Law, Uzbekistan(Email: x.burxanxodjaeva@tsul.uz) d.abdullayeva@tsul.uz)

which are enshrined in bilateral (and sometimes tripartite) agreements, are the formal expression of such regulation.

At the same time, international labour standards are a normative element of labour law, one of the achievements of modern development and the development of social policy instruments by the joint efforts of the international community, which are reflected in the results efforts by states to introduce social values into the market economy[1].

The content of these standards is a reflection of the experience of many countries, the formation of the most valuable and comprehensive principles and bases of the national labor law, the creation of practical rules with the participation of lawyers, the existing system of labor legal regulation, various views and approaches, various political forces and interests. The result of a collision of concepts involves finding a compromise legal formula that will be converted into international documents.

The date of March 2, 1992 is an important milestone in Uzbekistan's relationship with the international community. That day, Uzbekistan became a full member country of the United Nations. Currently, the Republic of Uzbekistan has joined the International Agenda for Sustainable Development, announced at the UN Summit, and has committed itself to meet the Sustainable Development Goals 2030 nationally.

According to A.Saidov, the International Labor Organization's conventions and recommendations are aimed at ensuring the rights of citizens. The states acceding to these documents undertake to adopt appropriate legislative measures and take practical measures to ensure human rights in the field of labor. These international obligations are recognized by the international community as the minimum standards for the social and legal protection of the individual [2].

It is important to note that the "Country Program for Correspondent Labor" is being implemented from 2017 to 2020. Within the framework of this program, measures are being taken to improve labor legislation in Uzbekistan, to raise awareness of labor rights and legal awareness of citizens, and to establish a mechanism for prompt response to violations of labor laws. Since 2018, the Office of the National Coordinator of the International Labor Organization (ILO) has been operating in Uzbekistan.

In general, the analysis of existing national labor legislation shows that international labor standards have 


\section{FOREIGN EXPERIENCE AND CURRENT LEGAL PROSPECTS RELATED TO THE TERMINATION OF A LABOR CONTRACT ON THE INITIATIVE OF AN EMPLOYEE AND AGREEMENT OF PARTIES}

been implemented in the national legal system. In addition, some of our national norms contain more favorable terms than those specified in the conventions. Here are some of the ILO conventions ratified by Uzbekistan.

The main priorities of the International Labor Organization are the implementation of 8 hours or 48 hours of work per week, the prevention and control of unemployment, protection of maternity and postbirth period, nighttime labor, the minimum working age [3].

The ILO Conventions can be classified according to their specifics in the spheres of human rights protection. The first type is the conventions establishing minimum rules in the field of labor, such as international conventions Convention No. 47 of 1935 on reducing working hours to forty hours a week, Convention No. 52 of 1936 on sabbatical, Convention No. 138 of 1973 on the minimum age, Convention No. 122 of 1964 on Employment policies can be included. The second type of these conventions is the conventions defining basic principles in the field of labor, including the Convention No. 111 of 1958 on discrimination in labor and Employment, the Convention No. 105 of 1957 on the abolition of forced labor, the Convention No. 29 of 1930 on forced labor, the Convention No. 100 of 1951 on equal pay for male and female workers, Convention No. 98 of 1949 on the right to collective association, and Conventions No. 154 of 1981 on collective council. At the same time, conventions governing certain categories of workers, namely Convention 182 of 1999 on the prohibition and abolition of severe forms of child labor, and Convention No. 103 of 1952 (revised) representatives of workers at 135 conventions in 1971.

The ILO Convention 158 and Recommendations 166 relate to the termination of labor contracts at the initiative of an employer. This Convention limits the termination of a labor contract at the initiative of the employer and presupposes its effect. Under article 4 of the Convention, an employer may not, on his own initiative, terminate a labor contract with an employee, regardless of his or her ability or conduct, or the need to produce an enterprise, organization or service [4]. Part 2 of Article 2 of the Convention lists categories of workers whose rules do not apply, which do not apply to:

labor contracts or seasonal workers (Articles 75-76 of the Labor Code);

Employees who have a probationary period or require a certain length of service (Articles 84-87 of the Labor Code) for a reasonable period of time (under national law, dismissal 3 days in advance will take effect during the trial period. Trial can be up to three months);

Employees who work for an indefinite period of time may not terminate an employment agreement with others, excluding the provisions of Article 4 of the Convention. Although this Convention is not ratified by the Republic of Uzbekistan, it sets international standards in the field of labor law and states that the adoption and implementation of these requirements in legislation is crucial for the protection of one of the most important human rights.

The Convention has now been ratified by 36 countries. It is important to note that the ILO Convention No. 158 on the abolition of employment on the initiative of an employer provides for a restriction where the number of employees to be dismissed is at least a certain percentage workers. 21 of the 27 industrialized countries, including Japan, England, Germany and Canada, have restrictions on the collective (mass) dismissal of more than 10 workers for economic and organizational reasons [5].

The 1932 Convention on Forced Labor may be included. Under this Convention, the term "forced labor" refers to the involvement of a person who has not offered to perform any job or service voluntarily, with the threat of using any or all of the above punishments (However, this term does not include military service, work or services that constitute ordinary citizen duties, works or services required by a particular court, and so on). The competent authorities may not permit any forced labor for the benefit of individuals, companies or communities. Any government body that makes such a decision will be held accountable.

Only in exceptional cases, public authorities may be forced to work, but these agencies may engage in such work only in exceptional circumstances, when no one voluntarily agrees. In these cases, only those under the age of 18 and men older than 45 years may be involved, except for persons with a doctor's opinion confirming that the worker is incapacitated, as well as students, teachers and school administrators. The maximum amount of forced labor cannot exceed 60 days a year. Another forced labor convention was adopted in 1930. The Convention on the "Protection of the Rights of Migrant Workers and Their Families" may be included in the same group of documents issued by the International Labor Organization. The Convention's provisions apply to migrant workers and during their migration, i.e. during preparation, migration, transit and paid work in the state, as well as during their return to the country. This Convention applies to migrant workers and their family members who are in the territory of another country regardless of sex, age, race, religion, nationality, language, political or other convictions, ethnicity, social status, citizenship, economic status, or family status.

Labor, vacation time, as well as remuneration, working hours and occupational safety issues. These types of documents include the Convention on the "Minimum Age for Children to Work in the Sea", 1936.

According to M.Mahamatov, national legislation may allow children under the age of 14 to work in accordance with their health and physical development, as well as in the best interests of children if the school or other competent authority deems it appropriate. Each captain or ship captain must record in his ship the employment of all persons under the age of 16 and their birthdays [6].

There are documents not only in specific areas of employment, but also with general admission age. These include the 1973 Convention on the Minimum Age for Employment. Member States of the International Labor Organization are encouraged to simplify child labor and carry out minimum national employment policies in line with national policies. Under the Convention, the minimum age should not be less than 15 years. The minimum working age can be set up to 14 years, in consultation with relevant

Published By:

Blue Eyes Intelligence Engineering

\& Sciences Publication 
Labor authorities (if any), with the member states of the International Labor Organization, whose economics and education are underdeveloped.

Hiring or other types of employment may be authorized by the relevant authorities to persons under the age of 16 , without prejudice to their health, safety or morals, as well as for specialization in a particular field.

The 1990 Labor Convention Convention, published by the International Labor Organization, may be included in the group. This Convention applies to all workers, except for agriculture, animal stuff, fisheries, marine and river transport. Night-time employees are entitled to appropriate health care and compensation benefits. If a worker becomes disabled at night, s/he will be transferred to another similar job s/he can perform.

This group also includes the 1981 Occupational Safety and Hygiene Convention. Under this Convention, Member States of the International Labor Organization will revise their national policies on occupational health, safety and production for a period of time. The main objective is to minimize occupational accidents and health damage. It is also worth mentioning the 1954 Convention on "Equal Promotion of Men and Women" for the same high-value labor. In the context of the Convention, the concept of incentive refers to any direct or indirect remuneration that an employee receives from an entrepreneur for doing something. This principle may be applied by national legislatures through collective bargaining agreements between employees and entrepreneurs, as well as by awarding or acknowledging by statute.

In conclusion, it is expedient to expand the ratification process of the ILO Conventions, a number of new Conventions will be implanted in national legislation and, hence, improve the labor legislation and ensure the priority of the new Labor Code.

Legal regulation of termination of labor contract in foreign countries on the initiative of the employee and agreement of the parties

Termination of the labor contract on the initiative of an employee and by the agreement of parties has a special place in the Commonwealth of Independent States countries. This legal institution is of special importance in the CIS countries and differs from the European model of contractual regulation of labor relations.

The analysis of the legislation regulating labor relations in the CIS countries can be found in the research work of J.Yu. Dorokhina [7], K.L. Tomashevsky [8], L.V. Sannikova [9], L.A. Chikanova [10] and others.

Unlike most Western European countries, labor laws in the CIS are codified. Many of them regulate labor relations with the Labor Code (Uzbekistan, Russia, Belarus, Kazakhstan, Tajikistan, Kyrgyzstan, and Latvia), and their legal provisions governing labor contracts are similar.

One of the biggest problems is the issue of termination of the labor contract, which is widely studied in foreign labor law, as it is directly related to ensuring the rights and freedoms of an employee. The following can be the basis for the termination of a labor contract in the western states:

firstly, the circumstances of the death of the employee or the employer or of other legal acts; second, the agreement of the parties;

third, the initiative of one party (unilateral act);

fourth, the liquidation of the organization;

fifth, expiration of the contract, completion of work specified in the contract;

sixth, force majeure, emergency circumstances (war, natural disasters, etc.);

and the seventh, the court decision to dismiss.

Also, workers in the labor law of such countries as Great Britain and Germany are more protected than those in other countries. Generally, in the laws of foreign countries, the termination of the employment agreement is carried out by the subject of the initiative, the termination of a labor contract by the agreement of parties, at the initiative of either party (employer or employee) and not independent of the parties [11].

The possibility of cancellation of labor contract by agreement of the parties in foreign literature is based on the contractual law and can be terminated according to the agreement between the parties. On this basis, there is difficulty in securing the parties' agreement, taking into account the specific difficulties of this situation, without denying the termination of the employment contract [12].

First and foremost, this is the case when an employer can use his or her powers, the dominant subject of labor relations, to force an employee to terminate employment relations on his own initiative or by agreement between the parties. This, in turn, allows the employer not to pay the various legal guarantees and compensation for the employee whose contract is terminated.

At the present stage of development of the right to selfemployment, there is no reason to doubt the legality of the termination of a labor contract at its own willingness. However, in the nineteenth century the termination of a labor contract by an employee was illegal and brought criminal liability [13].

As far as the French experience is concerned, the employment contract can be changed for economic or personal reasons. Economic reasons include staff cuts. The notice period is one month, and it may be up to 15 days in advance if the court reorganizes the organization [14].

The French Labor Code, which came into force on January 1, 2016, does not define the concept of "labor contract", but in 1954 the French Court of Cassation considered this notion. According to him, the labor contract (contrat de trail) is a contract for which one party is hired by the other party for a certain reward [15].

In German law, compliance with the written form is not compulsory in the process of concluding a labor contract, meaning that verbal labor agreements are also legally binding. According to the German experience, the termination of labor relations is subdivided into the types and causes of the termination through advance notice (ordentliche Kuendigung) and without warning (ausserordentliche Kuendigung) [16].

Dismissal in German labor law is made by applying for termination of a unilateral employment agreement. The

Published By

Blue Eyes Intelligence Engineering

\& Sciences Publication 


\section{FOREIGN EXPERIENCE AND CURRENT LEGAL PROSPECTS RELATED TO THE TERMINATION OF A LABOR CONTRACT ON THE INITIATIVE OF AN EMPLOYEE AND AGREEMENT OF PARTIES}

application must clearly state the purpose and timing for the employer. The purpose of the notice is determined by law or employment contracts. This period may also be extended for the employee. If there are any valid reasons, the employee may resign without notice. Based on judicial practice, these serious causes include untimely payment or sexual assault [17].

Among many benefits in German law, it is illegal for an employer to terminate a work contract during the pregnancy and up to four months after birth without the prior approval of the competent authorities [18].

It is important to note that the minimum notice period for the employment contract is legally defined in the UK and Japan. However, the order in which these countries are designated varies considerably. In the UK, in particular, the duration of the employee's employment with that employer is taken into account when setting the minimum notice period (continuous employment). Specifically, Article 86 of the Labor Rights Act states that if the employee has a regular working life of one month or more, the employee must notify the employer of his intention to terminate the labor contract within one week (unless otherwise stated in the employment contract) [19]. Also, if the employee has less than one month of service, the employee must notify the employer within a reasonable period of time (reasonable notice).

According to the Japanese Civil Code, an employee must notify the employer of his intention to terminate a labor contract two weeks in advance, and the minimum duration is not determined by the length of service and the rule is the same for all employees. According to the rule stated above, employers have the right to lay off employees, in turn, are entitled to retire. The Labor Standards Act provides specific restrictions on layoffs [20].

In the United States, labor relations have been shaped by the feudal system of England. Labor relations between employer and employee at that time were largely personal, with landowners' relations with peasants. Even today in the United States, the standard rule for employing private sector employers is that under the principle of "employment at will" employment can be terminated by employers because of disability or lack of certainty [21].

According to K. Lucasen and S. Schuster, M. Schchul, M. Wang, Switzerland is the most liberal in labor market regulation compared to other European countries and has adopted norms on labor contracting at the state level [22].

In the UK there is no practice of substituting warnings with material compensation. However, at the level of personal regulation, such practice is not illegal. From this we can conclude that the UK is the most attractive investment destination for foreign employers because the procedure for abolishing a labor contract in the UK is of the most liberal nature.

From the analysis of the legislation governing the termination of an employment on the initiative of an employee in the above-mentioned foreign countries, the extent to which the labor contract is terminated, the rights and guarantees of the employee are concerned with whether or not that country is attracting foreign investors directly related to the policy pursued by the state.
Improvement of legislation on signing, amending and terminating labor contracts

It has been 23 years since the establishment of the Labor Code of the Republic of Uzbekistan. Despite many reforms and changes in the country during this period, the norms of labor legislation lag behind modern requirements. Because labor legislation does not cover all the existing labor relations. At the same time, there are problems in labor relations that cannot be addressed even by the Labor Code.

Lawyer M.Yu. Gasanov has repeatedly mentioned in this regard. In his view, it is not enough to amend the Labor Code to address deficiencies. It needs to be revised. The Labor Code of the Republic of Uzbekistan, adopted in the new edition, regulates all complex relations in the field of hired labor in a single codified document, creates a legal framework to balance the interests of employees and employers, reducing the number of existing labor regulations (especially by-laws) eliminates inconsistencies and gaps in the regulation of labor relations and labor rights of employees provides active protection measures [23].

According to statistics, in January-December 2016 employment assistance was provided to 248, 200 citizens who applied for Employment Agency in 193 district (city) centers.

In the reporting period, 1108 job fairs were organized to reduce the timeframe for job seekers, which was attended by over 51,000 employers and nearly 165,000 job seekers. As a result of the fairs, 50.1 thousand people were hired, nearly 96,000 people were looking for jobs [24].

While these figures are increasing day by day, not every citizen has the right to work. One of the main directions of the state policy is not only the issue of employment of citizens, but also the stability of the labor contract with them and the guarantee of labor rights of employees. Therefore, it is necessary to harmonize the norms of labor legislation with the modern requirements and ensure that the Labor Code is the main document in protecting the rights and interests of the employers and employees.

We would like to propose that labor contracts should be entered into electronically in improving the legislation on the concluding, amending and terminating labor contracts, and, first of all, considering the interests of employees.

It is worth noting that today the Russian Federation has raised the issue of establishing electronic labor contracts and workbooks. At the same time, there is a need to conclude an employment contract electronically with remote personnel [25].

It is worth noting that some of Uzbekistan's leading scientists offer the introduction of electronic labor contracts [26].

It is proposed to conclude the labor contract electronically and to make appropriate amendments to the Labor Code of the Republic of Uzbekistan in light of the ongoing reforms in the country. At the same time, there are various opinions on the introduction of electronic workbook in our country. This indicates that in the near future, national labor legislation will be amended. 
The importance of electronic labor contracts is that it allows employers and employees to perform their work onsite by signing a labor contract remotely over the Internet. If such contracts are valid at the national level, a resident in one province will have the opportunity to work in another.

At the same time, employees do not have to leave their home, do not need to sign a lease to register in a temporary residence, and do not have any other difficulties. In particular, employees who are representatives of an enterprise do not have to go to the headquarters of the organization to sign employment contracts. It is not an exaggeration to say that the introduction of e-agreements will only bring about positive results. Therefore, it is proposed to adopt the Law "On electronic labor contracts and their registration in the Unified State Information Automated System" based on the results of the research.

Analysis of the norms of the Labor Code of the Republic of Uzbekistan on signing, modification and termination of labor contracts revealed a number of problems.

\section{RESULTS \& DISCUSSIONS}

In particular, the Labor Code of the Republic of Uzbekistan does not fully reflect the procedure for concluding a labor contract. In particular, the Labor Code does not specify the necessary and additional conditions that constitute the content of the employment contract. These terms are set out in the by-laws. However, based on the experience of foreign countries analyzed above, the terms of the employment contract are regulated by the Labor Code (Russia, Kazakhstan). Also, the Code does not specify the consequences of non-entering into any contract, which is a prerequisite for employment.

It is therefore proposed to amend Article 73 of the Labor Code as follows:

"Article 73. Content of the employment contract

The content of the employment contract is determined by the agreement of the parties as well as by labor legislation and other regulations.

Necessary conditions of the labor contract are:

place of work;

function of labor;

day of commencement of work;

wages and other conditions.

In cases stipulated by the legislation, the list of necessary conditions for conclusion of separate labor contracts (contracts) can be expanded.

In this regard, the scientist M.Yu. Gasanov notes that factual employment of an employee by the employer does not relieve him of the obligation of proper employment (making of employment contracts, issuance of orders for employment, etc.) [27].

With this in mind, section 82 of the Labor Code should include section 7 , which contains the following provisions:

"If an employee is authorized to work, the employer must enter into an employment contract and formalize employment within 3 days from the date of employment."

In our view, it is expedient to strengthen the basis of Article 97 of the Labor Code by terminating the employment contract with Part 4 of Article 89 of the Labor Code.
We also consider the following article to be included in the Code, since there is no clear procedure for terminating the employment contract by the parties:

"Article 97. Termination of labor contract by agreement of the parties.

Employer and employee may terminate any type of employment contract at any time upon agreement. The agreement must be at the discretion of both parties and should not be suppressed.

The employer and employee must fulfill their obligations under the employment contract before the date of termination of the employment contract specified in the agreement.

The date specified in the agreement will be the date of termination of the employment contract."

It should be noted that Article 100 of the Labor Code establishes that a labor contract may be terminated as a result of an employee misconduct. These include cases of systematic or one-time breach of duties by an employee. However, the list of cases, which is considered a gross violation, is not clearly specified.

According to the scientist A.P. Pantyukhina, the notion of the profession, specialty, position, and qualifications of the employee is essential for the validity of the termination of the labor contract due to non-performance or improper performance of the duties (duties, functions) of the employee. However, these concepts are not formally described in the Labor Code [28].

With this in mind, Article 11 should be included in the Labor Code and a description of all the key concepts used in the Code.

It is also necessary to make changes and additions to Part 2, Clause 4 of Article 100 of the Labor Code, which should be a list of actions that would be considered to be one-time gross violation of the employee's duties.

The Labor Code does not stipulate what measures should be taken by employers as a result of the employee's failure to perform temporary employment duties (such as dismissal or imprisonment under the CPC). Article 113 of the Labor Code provides for the dismissal of an employee, but there is no provision for temporary disqualification of an employee.

\section{CONCLUSION}

The norms of the Labor Code on concluding, modifying and terminating labor contracts were analyzed from the scientific and theoretical point of view, and as a result of the study the following conclusions were made:

1. Labor contract is a legal fact creating, changing and terminating labor and legal relations between an employer and an employee, except for related civil contracts.

2. A legal fact of termination of employment is an action or event in certain order. The facts are not legal when the conditions are breached.

3. The employment contract has its own distinctions from civil law contracts, and their use in practice can be a violation of employee rights.

4. The content of the employment contract is its necessary and additional terms, without which the legal effect of the employment contract is reduced. 


\section{FOREIGN EXPERIENCE AND CURRENT LEGAL PROSPECTS RELATED TO THE TERMINATION OF A LABOR CONTRACT ON THE INITIATIVE OF AN EMPLOYEE AND AGREEMENT OF PARTIES}

5. According to the Labor Code, employers' rights to change or terminate employment contracts are restricted and more workers are guaranteed. This shows the high level of social policy of the state.

6. Despite the fact that the Labor Code fully covers provisions for the conclusion, modification and termination of employment contracts, there are some problems with the application of these norms in practice. Also, the process of concluding, modifying and terminating an employment contract between an employer and an employee is not clearly described.

7. From the analysis of the ILO and European Council international treaties cited above, we can conclude that their terminology is uniform, although some terminological definitions are not the same.

8. Analyzing international acts on the termination of employment contracts, collective redundancies are initiated by the employer. The main purpose of these pilgrimages is to achieve a balance between the employer and employees, as well as the interests of the state. In other words, these international legal norms reflect the right of the employer to protect the employee from dismissal, against redundancy, as opposed to the right to dismiss an employee.

9. During the comparative-legal analysis of the experience of foreign countries, it became clear that the norms of the Labor Code of the Republic of Uzbekistan are not as detailed and exact as those set in the Labor Code of some CIS and European countries.

Based on the above conclusions, the following scientific and theoretical and practical suggestions were made as a result of the study to improve the legislation on the conclusion, amendment and termination of labor contracts:

1. The research explored the theoretical significance of the notion of a "labor contract", which resulted in a theoretical definition of the "employment contract".

2. It is proposed to adopt the Law "On electronic labor contracts and their registration in the Unified State Information Automation System" in order to introduce and regulate the process of concluding electronic contracts in the country based on the results of the research.

3. Employers' initiative should be restricted in order to further guarantee workers' rights when changing their employment contracts.

4. The following proposals have been elaborated to improve the grounds for termination of employment:

It is advisable to consolidate Article 97 of the Labor Code. It is necessary to include Article 97 in view of the fact that the Code does not contain a clear procedure for termination of the labor contract by parties. The notion of termination of employment agreement by parties is defined as follows.

According to it, the labor contract concluded within the established period, as well as the labor contract can be terminated in writing by mutual agreement of the parties, single document signed by the parties, as well as by postal, telegraph, teletype, telephone exchange. When concluding an employment contract, it is analyzed to include a provision that the parties must specify the date of termination of a labor contract and that the date of termination of a labor contract does not exceed six (6) months from the date of the agreement.

In our opinion, if the conclusions and recommendations of the study were taken into account in the improvement and reforming of labor legislation, labor rights of citizens would be ensured and in practice employers would prevent violations of the law.

\section{REFERENCES}

1. 1.Abaeva T.V. Legal regulation of termination of an employment contract by agreement of the parties and at the initiative of the employee: the dissertation ... PhD of legal sciences: 12.00.05 / Abaeva Tatyana Viktorovna; [Place of defence: Moscow State Law Academy named after O.E. Kutafina] .- Vladikavkaz, 2011.- 152 p.

2. International Labor Organization's major conventions and recommendations. // The editor in charge of the Uzbek edition - A.Saidov. - $\mathrm{T}$ : National Center for Human Rights of the Republic of Uzbekistan, 2008. p. 12.

3. 3.Pirmatov O. Aspects of development of general principles of labor relations in international private law. Labor Code of the Republic of Uzbekistan: Achievements and Prospects // Collection of Materials of the Republican Scientific and Practical Conference. $-\mathrm{T}$. TSUL, 2016. - p. 89.

4. International Labor Organization Convention 158 "On Termination of an Employment Agreement at the Employer's Initiative"// www.ilo.org сайти манбаси. http://www.ilo.org/dyn/normlex.

5. Alimov N. In the conditions of a market economy, it is necessary to protect employees. The newspaper is a Norma consultant. 2013. https://gazeta.norma.uz/publish/doc/text91917.

6. M.Mahamatov. International Labor Organization and Uzbekistan // Executive Editor: A.Kh.Saidov.-T .: National Center for Human Rights of the Republic of Uzbekistan, 2011. - p. 46

7. Dorokhina J.Yu. An employment contract under the laws of the Russian Federation and individual CIS member states: for example, the Republic of Belarus and the Republic of Kazakhstan: dis. ... PhD of legal sciences. M., 2009.

8. Tomashevsky K.L. Codification of legislation on changes to an employment contract in Belarus, Kyrgyzstan and Russia / K.L. Tomashevsky // Man and Labor. - 2000. No. 4.

9. Sannikova L.V. Employment agreement in Russia. / L.V Sannikova. - M.: MT-Press, 1999.

10. Chikanova L.A. Labor contract / L.A. Chikanova // Labor law. - 2004. - No. 4 - 5.

11. Stephan Hardly, Mark Butler. Europan Employment Laws: A comprative guide ( $3^{\text {rd }}$ edition). Great Britain. Ltd by: Short Run Press, 2016. - P. 133.

12. Treu T. Labour Law in Italy. Alphen aan Den Rijn, 2011. P. 110.

13. Jacobs A. Labour and the Law in Europe. Nijmegen, 2011. P. 92

14. Filipova I.A. Features of the legal regulation of labor under the laws of Russia and France. Reasonable matters. Monograph. - M., 2016. - P. 12.

15. Filipova I.A. Features of the legal regulation of labor under the laws of Russia and France. Reasonable matters. Monograph. - M., 2016. - P. 8. 
16. Employment law overview Germany 2019-2020 Pusch Wahlig Workplace Law / Proud Member of L\&E Global. P $\quad 18 . \quad$ https://knowledge.leglobal.org/wpcontent/uploads/sites/2/LEGlobal_Memo_Germany.pdf

17. "Labor law: the experience of comparative legal research: Monograph. (Lebedev V.M., Melnikova V.G., Nazmetdinov R.R. Norma, Infra-M, 2018. 294 p.

18. Rakhimov M.A. Labor law is an example of Germany. Law and Duty // \# 1/2018. P.35.

19. Giving Notice and Notice Pay // The Official Web-Site of Advisory, Conciliation and Arbitration Service (ACAS)

URL http://www.acas.org.uk/index.aspx?articleid=4095.

20. Atsushi Tsuneki and Manabu Matsunaka. Labor relations and labor law in Japan. Compilation (C) 2011 Pacific Rim Law \& Policy Journal Association. http://workspace.unpan.org/sites/Internet/Documents/UN PAN93857.pdf

21. Rakhimov M.A. Comparative overview of ways to protect workers' labor rights in Uzbekistan, Germany and the United States of America. 4 (75) -2017. p. 59.

22. K. Lucassen, S. Sluter, M. Shul, M. Wang. Corporate Law. Employment Law in Switserland // Journal of the International Institute for Law and Medicine. Editor Dennis Campbell. P. 172.

23. M.Yu.Gasanov. Prospects for the development of labor legislation in market relations. Materials of the roundtable. TSUL, 2015. - p. 6.

24. https://mehnat.uz/statistika/view/8.

25. www.pravo.ru.

26. Matrasulov DR Dynamics of Labor Code of the Republic of Uzbekistan. // Prospects for the development of labor legislation in market relations. Materials of the roundtable. TSUL, 2015. - p. 22.

27. M.Yu.Gasanov. Bridging the gaps in the legal regulation of public relations in the field of wage labor and further improving the Labor Code of the Republic of Uzbekistan. TSUL, 2016. - p. 18.

28. Pantyukhina A.P. Termination of the employment contract at the initiative of the employer on the grounds associated with the guilty behavior of the employee (theoretical and practical problems). Abstract of diss. PhD of legal sciences. M., 2013 .- p. 6-7. 